\title{
Poéticas urbanas para o terceiro milênio: um epos para o Rio de Janeiro
}

\author{
Valeria Rosito Ferreira*
}

\begin{abstract}
Resumo
Este artigo elege a poética de Rogério Batalha como uma voz renovadora na cena carioca de passagem de milênio. Especialmente em Melaço (2002) e Cidade Fundida (2012), o poeta transfigura a sensibilidade à violência urbana e aos imensos contrastes que oprimem a cidade do Rio de Janeiro em linguagem polifônica, e nos obriga a lidar sinestesicamente com riscos e perigos na cidade-poema recriada. Ao contrário de recorrer à poesia ensimesmada do gueto, seus poemas dialogam produtivamente com figuras e tradições literárias precedentes na busca por enfrentamentos do indizível, criando uma épica para a capital carioca. Sua matéria prima é composta de interrogações, repetições, aliterações e expressões parentéticas, além de um vasto repertório lexical de antíteses que recriam, na palavra, os entrechoques urbanos que, não raro, naturalizamos.
\end{abstract}

Palavras-chave: Poesia contemporânea. Rogério Batalha. Cidades. Rio de Janeiro.

\section{Urban Poetics for the third millenium: an epos for Rio de janeiro}

\begin{abstract}
This article elects Rogério Batalha's poetics as a reinvigorating voice on the Rio de Janeiro scene out at the turn of the millennium. Especially in Melaço (2002) and Cidade Fundida (2012), the poet transfigures sensitivity to urban violence and striking contrasts which choke up the city of Rio de Janeiro, Brazil, in polyphonic language, and forces us into synesthetically coping with risks and hazards within the poem-city recreated. Instead of resorting to the inward-looking poetry of the ghetto, his poems engage in productive dialogue with preceding literary figures and traditions in search for coping with the unspeakable, creating an epic for the carioca capital. His raw material is comprised of interrogations, repetitions, alliterations, and parenthetical expressions, in addition to a wide lexical repertoire of antitheses which recreate, along their words, the urban shocks we usually naturalize.
\end{abstract}

Keywords: Contemporary poetry. Rogério Batalha. Cidades. Rio de Janeiro.

Recebido: 01/06/2018

Aceito: 05/09/2018

* Universidade Federal Rural do Rio de Janeiro. Professora doutora associada de Literatura Brasileira. Membro do grupo de pesquisa GEDIR- Gênero, Discurso e Imagem. 
É na cartografia da cidade que as periferias e seus ocupantes se multiplicam ao mesmo tempo em que testemunham, em escalas variáveis, os percalços frente as (im)possibilidades de integração na urbs - geográficas e, principalmente, simbólicas. Não ao acaso, e na contramão dos discursos triunfalistas, que prometem Paris nos trópicos, a vida em cortiços urbanos, subúrbios e favelas é decantada aqui e alhures, desde que as cidades se 'modernizam' no século XIX e se incham no século XX. Não é de hoje, portanto, que um leque de qualificativos referentes ao distanciamento do 'centro' identifica a literatura e/ou a poesia alternativa como aquela que se constitui pela sensibilidade a crescentes e alarmantes contrastes, sobretudo, nessas arenas urbanas. 'Social', 'marginal', 'periférica', ou 'engajada' são apenas algumas das recorrências que procuram nomear a estética forjada por escritores e poetas cujas temáticas endereçam os desvalidos e as mazelas urbanas ao longo do século XX, como se pode dizer do modernismo de um Manuel Bandeira já desde os anos 1920, com o seu "Meninos carvoeiros", ou "O bicho" (1947), entre outros. Naquele momento, era espanto o sentimento expresso pelo eu poético que mal conseguia discernir a humanidade daqueles que eram obrigados a revirar lixeiras para comerem: “[...] Quando achava alguma coisa,/ Não examinava nem cheirava:/ Engolia com voracidade.// O bicho não era um cão,/Não era um gato, / Não era um rato. // O bicho, meu Deus, era um homem. (https://espacoluau.wordpress.com/2013/07/19/breve-reflexao-sobre-um-poema-demanuel-bandeira/) As mais de sete décadas que separam aquela observação da de seu companheiro contemporâneo podem não ter alterado a realidade urbana, mas certamente testemunharam a multiplicação de tais cenas e, talvez por isso, modificaram a maneira de expressar o horror diante delas. Na passagem para o terceiro milênio, ocupantes de áreas periféricas das maiores cidades do país, como Ferréz, Sergio Vaz e Rogério Batalha, animam o fazer poético e valorizam lugares de fala particularizados, lugares esses que passam a disputar, não sem polêmica, a própria legitimidade do que tais poetas têm a dizer. A ressalva se justifica pois, embora reconhecendo que os termos de um enunciado, ainda que idênticos, se tornam outros ao mudar de boca (BAKHTIN, 1981, p. 159), parece-nos salutar lembrar que a própria teoria bakhtiniana do discurso se ancora, sobremaneira, na autenticação de vozes validadas pela realização do diálogo. Por isso mesmo, ressaltada a legítima 'interioridade' das vozes de tais poetas - afinal o circuito em que transitam, assim como os referentes que endereçam lhes assegura um lugar "periférico" - não se pode afirmar tratar-se da reivindicação $a$ priori de um essencialismo originário do gueto. Ao contrário, suas lavras reverberam vozes literária e historicamente ancoradas, muitas das quais canônicas, em trabalho estético sofisticado e linguagem apurada, que não se confunde com panfletagem palatável, ao gosto do mercantilismo fácil, que elege representantes e representações discutíveis nas chamadas “falas de dentro". No caso em questão, essa poética urbana dialoga produtivamente com a herança cultural mais ampla em que seus poetas fazem questão de se inscrever e transformar.

Estas considerações se ocupam, específica e exemplarmente, da poética de Rogério Batalha em duas de suas produções do novo século: Melaço (2002) e Cidade Fundida (2012). Natural de Miguel Couto e "curtido na Penha"- como se auto identifica - o poeta, letrista e professor de literatura Rogério Batalha vem circulando sua poesia, especialmente a não musicada, em edições do autor, como é o caso de dois de seus livros de finais do século passado - Malícia e Bazar barato, de 1998 e 1999, respectivamente. Parte de seus escritos também pode ser encontrada em blogs como o http://letraspoetaletrista.blogspot.com rogeriobatalha.blogspot.com. Rogério Batalha encontra sua matéria-prima na 'cidade fundida'. É no Rio de Janeiro ‘fundido' entre o elegante Leblon, de um lado do túnel, e o chacinado Vigário Geral, do outro, que o poeta enxerga lados nada partidos entre si, promiscuamente intercomunicantes. Suas peças poéticas, além de endereçarem o universo urbano, se constroem com recurso a uma linguagem adensada pelas tensões que referenciam, ressaltando, assim, seus próprios referentes citadinos. Posto de outra forma, a brutalidade do conteúdo referencial que sublinha a vida na cidade de que trata o poeta mantém relação inextricável com a linguagem lavrada, ela própria 
incômoda e brusca. A cidade se antropozoomorfiza e passa de cenário a interlocutora privilegiada, num jogo arriscado por meio do qual a memória fragmentada se figura como 'ruína', e desafia a linearidade das narrativas convencionais. Nos termos do próprio poeta "a cidade é uma substância antropomorfa/ com seus pingentes /(de rocha verde)/ forja / (em ferro e brasa) / muiraquitãs e asas" (BATALHA, 2012, p.19). Rogério Batalha resgata a palavra do mundo das mercadorias ao mesmo tempo em que põe em xeque convicções sobre a natureza distópica, economicamente fragmentada e esteticamente espectral de nossos dias, pois desperta todos os nossos sentidos para reanimar o mundo gasto e corrompido que endereça. Apropria-se de signos espaciotemporais e depura-os numa linguagem livre de condicionantes ideológicos, ou estreitamente reduzida aos ditames da hora.

Começamos por tomar o ensaio "Sobre o conceito da História", de Walter Benjamin (1994), escrito em 1940, como base teórica para endereçar a matéria poética que nos interessa, tendo em vista a aproximação que ele nos permite entre a história das cidades e a sensibilidade de Batalha. Diante do fracasso de modelos históricos que pudessem explicar a devastação do continente europeu no entre guerras, o filósofo alemão recorre à metáfora fotográfica para, então, pensar os instantâneos capturados pela câmera como estratégias sensíveis que desmontem o continuum coerente das histórias oficiais, responsável pela "empatia com os vencedores" (BENJAMIN, 1994, p. 225). Sugere que "a história é objeto de uma construção cujo lugar não é o tempo homogêneo e vazio, mas um tempo saturado de agoras" (BENJAMIN, 1994, p.229, grifos do autor). Percebemos que os esforços do pensador se debruçam sobre a organização do próprio contemporâneo se, no rastro etimológico, identificarmos a presença de vários tempos coexistentes e sobrepostos. Seja na história ou na literatura, aproximadas por suas naturezas discursivas, o rompimento dos elos aparentes (e coesivos) entre passado e presente é percebido, portanto, como força emancipatória e desejável, para que os vários tempos justapostos e desordenados possam apresentar (e não 'representar') o passado, como conjunto de disputas e lutas, tornando-o matéria viva e heterogênea no presente adensado.

Ostentando um repertório imagético estruturante ao seu pensamento, Benjamim referencia o quadro Angelus Novus do pintor Paul Klee para expressar tal percepção:

[O quadro] representa um anjo que parece querer afastar-se de algo que ele encara fixamente. Seus olhos estão escancarados, sua boca dilatada, suas asas abertas. O anjo da história deve ter esse aspecto. Seu rosto está dirigido para o passado. Onde nós vemos uma cadeia de acontecimentos, ele vê uma catástrofe única, que acumula incansavelmente ruína sobre ruína e as dispersa a nossos pés. Ele gostaria de deter-se para acordar os mortos e juntar os fragmentos. Mas uma tempestade sopra do paraíso e prende-se em suas asas com tanta força que ele não pode mais fechá-las. Essa tempestade o impele irresistivelmente para o futuro, ao qual ele vira as costas, enquanto o amontoado de ruínas cresce até o céu. Essa tempestade é o que chamamos progresso ( BENJAMIN, 1994, p. 226).

A força dos condicionantes que impelem o movimento progressivo da técnica, do capital, e, em última análise, da história, prosseguirá o filósofo, redundará na história universal, aquela que embala homogeneamente o progresso de 'parte da humanidade' - os "vencedores", nos seus termos -, e equivocadamente retratada como representante do conjunto e do movimento de todas as suas classes ou segmentos sociais. O anjo de Klee, na leitura de Benjamin, é susceptível ao progresso, embora resista a ele, e não pode se não deixar-se sensibilizar pela avalanche de ruínas, de fragmentos que testemunham o colapso do ritmo imprimido pelos governantes e políticos apoiados pelas massas. (BENJAMIN, 1994, p.227)

A poética de que nos ocupamos toma para si a tarefa de restituir a história ao "tempo saturado de agoras". De forma ampla, a natureza do fazer poético, ao contrário da prática comunicativa referencial, se ocupa da identificação e/ou pela produção da coexistência de dimensões temporais e espaciais do real pela sugestão da palavra. E nesse sentido primordial de palavra reverberada, todo esforço poético se dirige à "saturação de agoras". Sendo assim, as considerações do pensador alemão sobre a história atingem um terreno muito mais amplo do que aquele ocupado pela história como ciência, 
pois acaba por sugerir-lhe uma filosofia afastada da racionalidade discursiva e aproximada da poesia - nos termos aristotélicos da poética antiga, uma história mais "elevada" por encerrar, como a poesia, “o acontecido e o não acontecido" (ARISTÓTELES, 1997, p. 28). Em última análise, a poética de Batalha responde por entrechoques de temporalidades distintas e dispersas, assim como de tradições e realidades conflitivas, que se imbricam e se revelam através de recursos complexos de linguagem. Faz da memória o resultado estético do lembrar e do esquecer. No rastro de Benjamin, não se trata de somente "conhecer o passado como ele de fato foi", mas "apropriar-se de uma reminiscência, tal como ela relampeja no momento de um perigo" (BENJAMIN, 1994, p. 224).

Tais momentos de perigo são numerosos na cidade e exigem atenção extrema do poeta, que os desafia e os enfrenta com as armas poéticas que lhe podem fazer face. A epígrafe que antecede seus vinte poemas em Melaço: "Sagacidade é saber farejar delícias!", aponta para um eu poético 'bicho', não porque tenha se desumanizado, como aquela personagem poética de Manuel Bandeira que revira as lixeiras, mas porque, ao se animalizar, torna-se mais potente, mais sensível às delícias misturadas aos dejetos, imperceptíveis ao olfato meramente humano. "Costurar/ mirra e/ merda", como reitera seu poema de abertura, não nos deixa dúvidas sobre a inextricabilidade dos contrastes que se expõem ao rapsodo urbano, "(cara a cara) /entre a pelúcia/ e a piaçava” (BATALHA, 2002, poema 00). São cortantes ou impactantes suas ferramentas, assim como oscilam entre a maciez e a aspereza as superfícies que toca porque "não existem/ Beijos sem lâminas" BATALHA, 2002, poema 10) e "A martelo e bigorna/ Aliás, como deve, a poesia.” (BATALHA, 2002, poema 3, parte 3). Muito embora o poeta persevere em movimentos de escavação e penetração, como transparece também nos poemas Cavar (BATALHA, 2002, poema 1) e Penetra (BATALHA, 2002, poema 2), a realidade poética encontrada parece não se prometer como um fim à reiterada busca de "cavar, lavrar/ o rés-do-chão." (Ibid, poema 1), mas, ao contrário, se prova suficiente no presente incansável de quem "desaloja [r] / todos os trapos do dia-a-dia" BATALHA, 2002, poema 2 ). A experiência cavada e lavrada por essa poesia urbana é sinestésica:

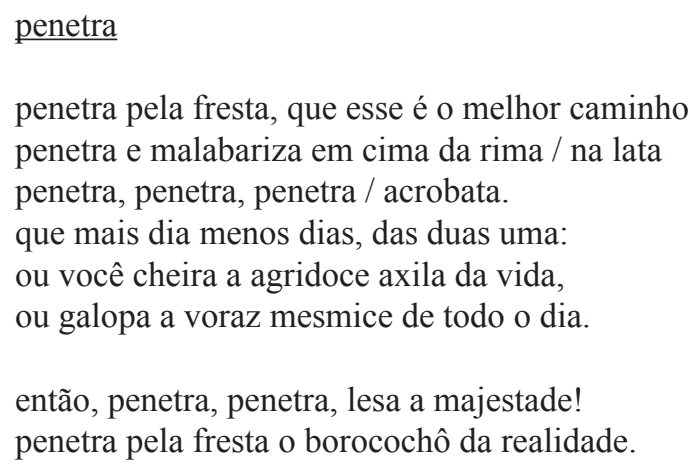

A sugestão de que faro, tato, audição e paladar se conjuguem para a aproximação da "realidade", atingível não como um todo, mas 'por uma fresta' - afinal, são ruínas que se depositam aos pés do anjo de Klee - vem anunciada pela explosividade das bilabiais no reiterado "penetra"; prossegue nas acrobacias mandatórias de quem vive nos extremos, e conclui-se na sugestão de um 'cheiro-paladar' agridoce, produzido por uma parte do corpo que, se carece de nobreza, excede em sensibilidade. A saturação sinestésica se coloca como uma urgência, sem cujo atendimento a priori não se 'realiza' o que se entrevê pela fresta penetrada. Sem farejar cheiros contrastantes, vislumbrar a cor da palavra, e sentir a textura das coisas, o poeta só tem a lamentar: "Sinto muito", manifesta-se em "Poema Afroreggae", um dos mais longos de Melaço: 


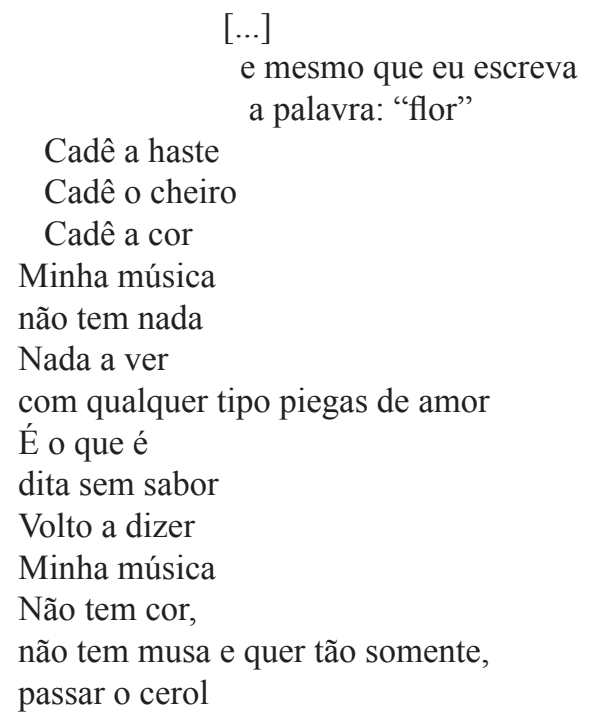

(BATALHA, 2002, poema 3, parte 1).

Na cidade-poesia, sua linguagem também dá mostras de inesperados entrechoques: "melaço" - se forja entre a doce gosma do mel e a acre solidez do metal. A ausência de liames entre seus versos dificulta a organização de sentidos (azeitar a sintaxe, afinal, pode também ser um atenuante vil ao horror do irrepresentável). Palavras soltas e recorrentemente repetidas em mutações paronímicas e geração de aliterações, atropelam a si mesmas e a nós, leitores e ouvintes, na velocidade de quem corre pela vida:

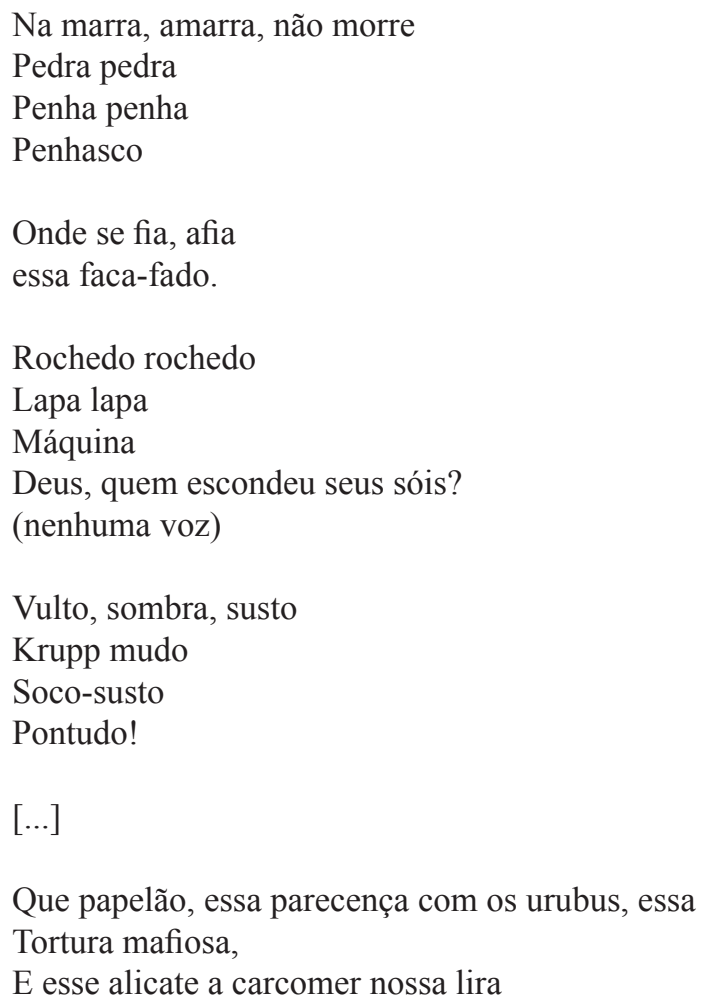

(BATALHA, 2002,poema 3, parte 1

Além da repetição lexical, a constelação terminológica, organizada em torno de pedras, penhas, lapas e penhascos, ressignifica-se como nomes próprios na cartografia fluminense, onde a natureza rochosa permanece indiferente diante das mutações humanas e abandono histórico sofrido pelo centro e pelos subúrbios cariocas, possíveis terras do poeta-Prometeu: Lapa, Rocha e Penha - com maiúsculas. 
Abruptos saltos de um a outro verso, como filme sem continuidade, nos subtraem a sintaxe a fio de faca, imagem recorrente, como a da pedra, no "Poema Afroreggae", elaborado a propósito da chacina de Vigário Geral, no Rio de Janeiro. É por justaposição imagética (e continuidade do desespero) que o poeta do século XXI une-se ao condoreiro do século XIX, para também escovar a história a contrapelo, como evidenciam os extratos de "Vozes d'África", de Castro Alves:

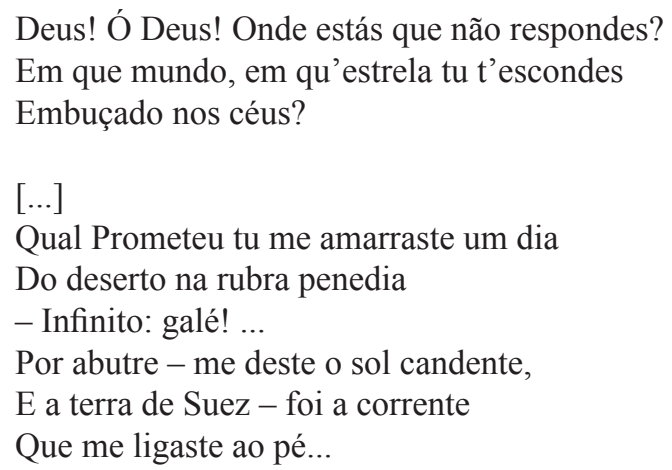

A interpelação a Deus no poema do século XXI, como no poema de 1868, se queda sem resposta. No passado, como no presente, as perguntas aos gritos referenciam o que foi ocultado ao eu poético: a resposta para seu sofrimento, a marca na epiderme que o escraviza, por sua diferença, há dois mil anos. Lá, Deus, ele mesmo, se furta; aqui, no presente, a metonímia na figuração de "seus sóis" realiza a aproximação ideológica do ocultamento e da crueldade divina. Do deserto bíblico e escaldante, metáforas para abutre e corrente, a tortura perdura no presente, com os urubus e o alicate a "carcomer a lira", que exigirá, supõe-se, um abandono das cordas rumo ao sopro épico... A esse respeito, declara o poeta que "Minha música/ não sabe onde pôr/ o coração" (BATALHA, 2002, poema 03, parte 1).

A par da estética "cerol fino" do poeta, há de se observar que a ausência de conectivos no corpo do poema já assinalada é revertida ao fim de sua primeira e de sua sétima e última parte, com a introdução de uma concessiva, "E mesmo assim, Afroreggae", referenciando o movimento cultural comunitário deflagrado exatamente a propósito da chacina de Vigário Geral. Choca-se com a antecedência de uma alternância longa, entre um bordão-disparo "podrepodre", que se repete desde o final da parte 1 até o final da parte 7, e os particípios "desarranjado, quietado, imobilizado, derramado, terminado, extraviado, insultado, degolados, dilacerados, extirpados, assassinados, retalhados, encerrados, empacotados" (partes 6 e 7). A concessiva reforça a crença na resistência da poesia - "cerol fino" cortante que deve ser "Para remar/ Capinar/ Amar amar/ Resistir, jamais recuar" (parte 1). Pontifica o poeta em "Mirra e merda" que "costurar/ mirra e/ merda/ é o que mais me interessa!" (BATALHA, 2002, poema 00).

Em contraste com a proposta de apreensão do real por meio da incansável sensibilização poética, a falsificação daquele real se dá ainda pela ação positiva e atordoante dos meios de comunicação de massa:

\author{
$[\ldots]$ \\ Será a felicidade objeto UFO? \\ Que nada! \\ Alô alô rapaziada \\ Estão chegando as mulatas \\ Atenção atenção Srs. Telespectadores \\ Não deixem para amanhã \\ $\mathrm{O}$ que se pode fazer hoje \\ Em virtude do campeonato nacional \\ Melhoral é melhor e não faz mal! \\ (BATALHA, 2002, poema 3, parte 2).
}


Ao invés de exacerbarem a potência sensorial, como o faz o poeta, os mass media atuam no sentido contrário, ao anestesiarem a sensibilidade do observador/ator, fazendo esvair possibilidades emancipatórias daqueles que se tornam meros consumidores do espetáculo da cidade: entretenimento, saúde ou política, tudo se homogeneíza no vazio da tela. É falsa a pretensão de que, nos termos ainda de Benjamin, a retratação detalhada da realidade objetiva pela multiplicação de lentes e/ou de métodos de reprodução, acrescente um quantum favorável à produção da verdade. Somente por consequência da técnica, torna-se possível à arte oferecer "o que temos direito de exigir da arte: um aspecto da realidade livre de qualquer manipulação pelos aparelhos, precisamente graças ao procedimento de penetrar, com os aparelhos, no âmago da realidade" (BENJAMIN, 1994: 187). Como se ecoasse o filósofo, o poeta pontifica: "Pois nenhum exame balístico registrará/ a causa morte da tristeza da menina. /" (BATALHA, 2002, poema 03, parte 3).

Liberdade é condição e resultado da poesia, sem a qual ela se rende à palavra engessada e estéril. O poeta ensina:

Pois a poesia não se reproduz em cativeiro

A poesia cisca no quintal do seu grito

O poema se não lâmina-pluma

Toma chá de sumiço. (BATALHA, 2002, poema 03, parte 4 ).

Nos contrastes ainda, dessa vez, táteis, entre a leveza da pluma e o peso da lâmina, a poesia atravessa novo teste, seja de equilíbrio, de resistência, de tenacidade. Como sugerido anteriormente, o motivo onomatopaico disparado persistentemente ao longo do poema - "podrepodre" - volta em conclusão ao final da última parte com referentes mais factuais à chacina-mote do Poema Afroreggae:

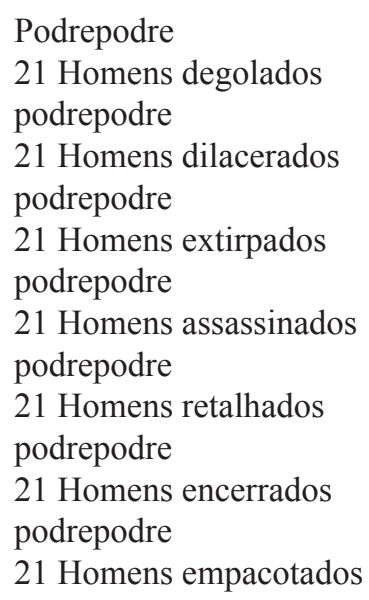

Mas mesmo assim, Afroreggae. (BATALHA, 2002, poema 3, parte 7 ).

O numeral ali é contundente, mas não panfletário. Coroa o trabalho sugestivo feito ao longo do poema, com resultado 'contábil', pronto talvez para alimentar a notícia de jornal, essa sim, alheia a tudo que dimensione a Humanidade - com " $\mathrm{H}$ " maiúsculo - daqueles que viveram e morreram como mera estatística.

É no palco da cidade contemporânea que a costura de "mirra e merda" encontra sua expressão mais contundente. Em Cidade fundida (BATALHA, 2012), o poeta retoma uma década mais tarde a figuração da cidade como expressão central de seus versos. A identidade da cidade, assim como sua paisagem, não é nítida - "Aqui paisagem nítida não há” - (BATALHA, 2002, p. 15), como tampouco são nítidos os limites que separam a urbs de seus habitantes. Como sugerido nos poemas de Melaço, a identidade urbana parece ser muito mais um modus operandi que um traço essencial de sua natureza. Essa percepção aproxima a experiência urbana do delírio poético, expresso como incerteza onírica na sequência de interrogativas: 


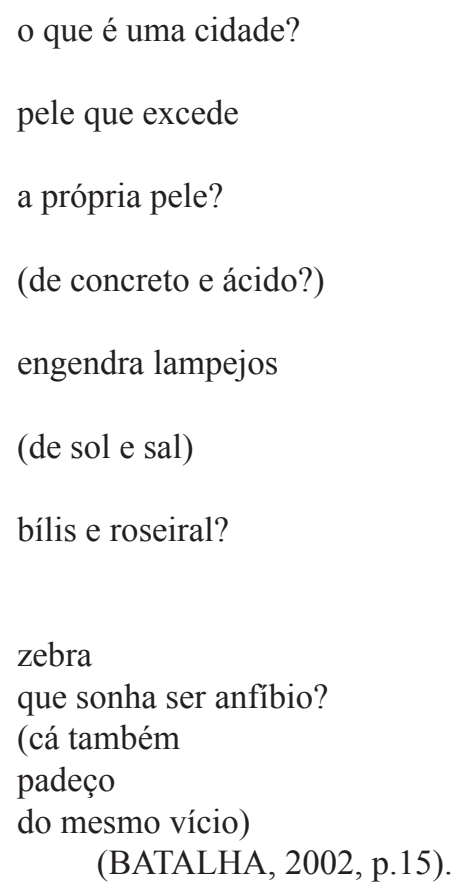

A sensibilidade aguçada e febril do eu poético, que experimenta a dissolução de limites entre sua pele e a 'pele' urbana, atinge seu momento climático na sugestão de fusão de dois corpos. O da cidade, recorrentemente metaforizado como um corpo feminino, contorce-se em dor e êxtase vertiginosos:

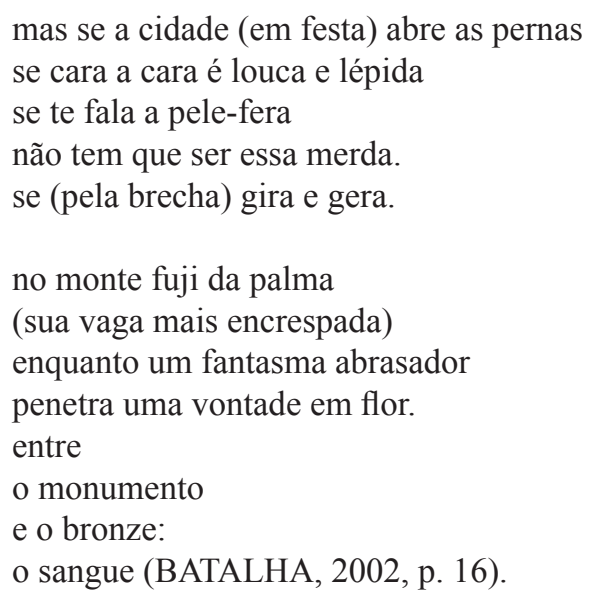

A vitalidade da cidade que sangra fundida coexiste, ironicamente, com a realidade da cidade monumental. Fundidos nas estátuas urbanas, os registros da memória oficial são eternizados no bronze sólido de seus monumentos e de suas armas. "Sangue" e "bronze", aproximados no poema, sugerem, adicionalmente, a justaposição de camadas de memória, perceptíveis ao poeta, que enxerga sangue onde se ostenta o bronze de uma idade de guerras e de monumentos à devastação civilizatória. Flagra, como que pelo instantâneo fotográfico, as ruínas urbanas que lhe "relampejam como num momento de perigo" (BENJAMIN, 1994, p. 224). Afinal, o poeta sabe que cultura e barbárie se fundem e que "nunca houve um monumento da cultura que não fosse também um monumento da barbárie" (BENJAMIN, 1994, p. 225). Como Walter Benjamin nos anos 1930, os pensadores que pensam o tempo por meio da justaposição sincrônica, como o italiano Giorgio Agamben (2009), fazem uso de recursos imagéticos na criação de metáforas que sugiram o inexorável desconforto daqueles que se contorcem - como o anjo da história, já examinado - entre forças contrárias e concorrentes. A propósito também de uma incursão pela arte, desta vez, a poética, Agamben atravessa o poema O século, de 1928, de Osip Mandel'stam, num comentário digno de citação pela proximidade, até mesmo lexical, de muitas das escolhas de Batalha: "O poeta, que devia pagar sua contemporaneidade com a vida, é aquele que deve manter fixo o olhar nos olhos do seu século-fera, soldar com o seu sangue o dorso quebrado do 
tempo." (Ibid, p. 60). Atentemos, no prosseguimento da análise do pensador, para sua insistência em sublinhar termos como "fratura" e "sangue" quando repassa a missão do poeta: "O poeta, enquanto contemporâneo, é essa fratura, é aquilo que impede o tempo de compor-se, e, ao mesmo tempo, o sangue que deve suturar a quebra" (AGAMBEN, 2009 p. 61). A título de fechamento desta sequência de citações, vale ainda ressaltar a semelhança entre a figura do "neonato", apresentada por Agamben, e aquela tomada de empréstimo de Paul Klee por Benjamin:

Que se trate de uma tarefa inexecutável - ou, de todo modo, paradoxal - está provado pela estrofe sucessiva que conclui o poema. Não apenas a época-fera tem a vértebras fraturadas, mas vek, o século recém-nascido, com um gesto impossível para quem tem o dorso quebrado quer virar-se para trás, contemplar as próprias pegadas, e, desse modo, mostra o seu rosto demente: (AGAMBEN, 2009, p. 62)

Na medida em que o poeta contemporâneo se vê obrigado a manter o olhar fixo no seu tempo e enxergar, não as luzes, mas a escuridão de sua época, compreende-se que Batalha emblematiza, na periferia mundial e nas guerras urbanas não oficialmente declaradas, a contemporaneidade em sua quintessência na urbs.

É de se notar ainda, passando a comentar a linguagem emprestada ao Cidade fundida, que o próprio poema é personificado a partir de um compasso respiratório que lhe é imprimido. Recorrentes versos parentéticos lhe permeiam, do começo ao fim, um ritmo polifônico, entrecortado como que por vozes que comentam, acrescentam, ou se contrapõem à linearidade do movimento da escrita/fala ou do tom da fala predominante: um coro trágico, qual um fole, nos obrigando a ouvir de vários lugares e em outros tons ao mesmo tempo, a suspender a respiração por vezes, já que a vida na cidade exige o apuro de todos os sentidos: "(chocalho de cobra)/ o poema é um local de desova..." (BATALHA, 2012, p. 15)

Ensina-nos Bakhtin (BAKHTIN \& VOLOCHÍNOV, 2006) a esse respeito que

[...] a palavra penetra literalmente em todas as relações entre os indivíduos, nas relações de colaboração, nas de base ideológica, nos encontros fortuitos da vida cotidiana, nas relações de caráter político, etc. As palavras são tecidas a partir de uma multidão de fios ideológicos e servem de trama a todas as relações sociais em todos os domínios. É portanto claro que a palavra será sempre o indicador mais sensível de todas as transformações sociais, mesmo daquelas que apenas despontam, que ainda não tomaram forma, que ainda não abriram caminho para sistemas ideológicos estruturados e bem-formados. A palavra constitui o meio no qual se produzem lentas acumulações quantitativas de mudanças que ainda não tiveram tempo de adquirir uma nova qualidade ideológica, que ainda não tiveram tempo de engendrar uma forma ideológica nova e acabada. A palavra é capaz de registrar as fases transitórias mais íntimas, mais efêmeras das mudanças sociais. (BAKHTIN \& VOLOCHÍNOV, 2006 p. 42).

A par do que chamamos de 'coro trágico', perceptível no Cidade fundida, talvez como um correspondente a essa "fase transitória íntima" das mudanças sociais, de que fala Bakhtin, tonificamse metáforas e movimentos já aparentes no antecessor Melaço. Apontamos naquele momento como as sugestões impressas em "cavar" inclinavam-se mais ao incessante caráter processual da poesia, que rejeita um fim outro que não seja o de sua própria libertação pela linguagem. Aqui neste poema, embora o movimento para o interior continue em "escavar", o poeta também acaba por fundir preposição e verbo no último verso da sequência, obrigando-nos a uma leitura sonorizada, livre do grafocentrismo:

A escavar

escavar

escavar

(em busca de algum mar)

a escavar escavar escavar

ilusórias ossadas 


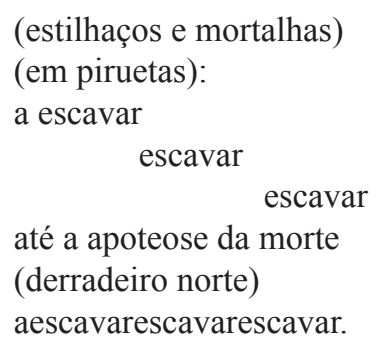

(BATALHA, 2012, p. 17-18).

Misto de paleontólogo e arqueólogo, o poeta define também a cidade e sua própria cidadania (privilegiada?) como aquela a ser exercida por seres híbridos, míticos, tribalistas do asfalto:

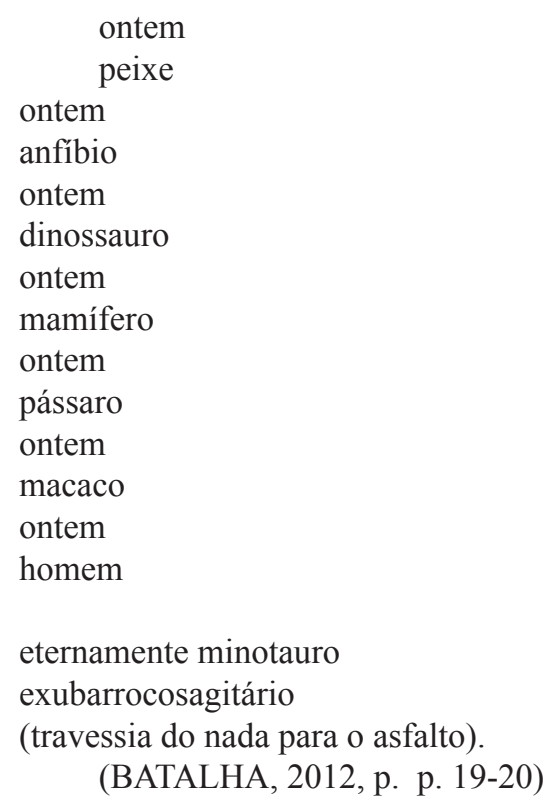

A escala evolutiva proposta na primeira estrofe é somente aparente, pois, como já sugerimos, a cidade não resulta triunfante de uma época gloriosa das luzes; não emerge linear ou progressivamente e o homem urbano e contemporâneo deve saber renunciar a uma humanidade soberba e plena de si mesma.

O fim das utopias, se coincide com a entropia sócio urbana, não parece deflagrar, necessariamente, a paralisia de movimentos estético-políticos que se organizam como proposições para o milênio. A julgar pelas amostras examinadas, essas gerações finesseculares de poetas e escritores que vivem, sentem e pensam a cidade do século XXI, como o faz Rogério Batalha, respondem em suas vísceras à dinâmica histórica e aos desafios estéticos com engajamento político e criatividade surpreendentes, fato que relativiza as versões consolidadas sobre a natureza desrealizada da contemporaneidade. É fecundo o diálogo com o passado literário e poético em que se incluem essas gerações expressivas das periferias. Suas marcas biográficas são parte de uma experiência alargada que passa a constituir uma memória saturada, muito mais ampla do que propõem os discursos oficiais.

Entre o "negrorazul do cós ao cu" na cidade fundida em Rogério Batalha, somos golpeados por uma dicção renovadora da poética urbana. Uma lavra requintada dispara petardos que desequilibram a história oficial e obrigam ao alargamento do eu poético. Inserções corajosas e sofisticadas fundem também estética e história num presente comprimido, polifônico e arriscado. 


\section{Referências}

AGAMBEN, Giorgio. "O que é o contemporâneo?" In: AGAMBEN, Giorgio. O que é o contemporâneo? e outros ensaios. Tradução de Vinícius Nicastro Honesko. Chapecó: Argos, 2009. ARISTÓTELES. HORÁCIO. LONGINO. A poética clássica. Tradução de Jaime Bruna. 7. ed. São Paulo: Cultrix, 1997.

BAKHTIN, Mikhail. Problemas da poética de Dostoiévski. Tradução de Paulo Bezerra. Rio de Janeiro: Forense-Universitária, 1981.

BAKHTIN, Mikhail . E Volochínov, V.N. Marxismo e filosofia da linguagem; problemas fundamentais do método sociológico na ciência da linguagem. Tradução de Michel Lahud e Yara Frateschi Vieira. 12. Ed. São Paulo: Hucitec, 2006.

BANDEIRA, Manuel. "O bicho", disponível em: <https://espacoluau.wordpress.com/2013/07/19/ breve-reflexao-sobre-um-poema-de-manuel-bandeira/ > Acesso em 20 out 2017.

BATALHA, Rogério. "Cidade fundida". In: ROSITO, Valeria (Org.). Cidade fundida: tal centro, qual periferia? Rio de Janeiro: EDUR, 2012.

BATALHA, Rogério . Melaço. Rio de Janeiro: Bizu, 2002.

BATALHA, Rogério . http://letras-poetaletrista.blogspot.com

BENJAMIN, Walter. "A obra de arte na era de sua reprodutibilade técnica”. In: BENJAMIN, Walter . Magia e técnica, arte e política: ensaios sobre literatura e história da cultura; obras escolhidas, v. I. Tradução de Sergio Paulo Rouanet. São Paulo: Brasiliense, 1994, pp. 165-196.

BENJAMIN, Walter . "Sobre o conceito da história”. In: BENJAMIN, Walter. Magia e técnica, arte e política: ensaios sobre literatura e história da cultura; obras escolhidas, v. I. Tradução de Sergio Paulo Rouanet. São Paulo: Brasiliense, 1994, pp. 223-232.

CASTRO ALVES, Antônio Frederico de. Vozes d'África [1868]. Disponível em: <http://www. jornaldepoesia.jor.br/calves02.html>. Acesso em: 20 fev. 2012. 
